\title{
ANTIOXIDANT ACTIVITY OF PROTEIN HYDROLYSATES FROM RAW AND HEAT-TREATED YELLOW STRING BEANS (PHASEOLUS VULGARIS L.)
}

\author{
Monika Karaś ${ }^{1 凶}$, Anna Jakubczyk ${ }^{1}$, Urszula Szymanowska, Małgorzata Materska², \\ Ewelina Zielińska ${ }^{1}$
}

${ }^{1}$ Department of Biochemistry and Food Chemistry, University of Life Sciences in Lublin

Skromna 8, 20-704 Lublin, Poland

${ }^{2}$ Department of Chemistry, University of Life Sciences in Lublin

Akademicka 13, 30-950 Lublin, Poland

\begin{abstract}
Nowadays, legume plants have been considered not only a source of valuable proteins necessary for the proper functioning and growth of the body but also a source of bioactive compounds such as bioactive peptides, that may be beneficial to human health and protect against negative change in food. The aim of this study was to investigate the effect of heat treatment on the release of antioxidant peptides obtained by hydrolysis of the yellow string beans protein. The antioxidant properties of the hydrolysates were evaluated through free radical scavenging activities (DPPH and ABTS) and inhibition of iron activities (chelation of $\mathrm{Fe}^{2+}$ ). The results show that the heat treatment had influence on both increased peptides content and antioxidant activity after pepsin hydrolysis of string bean protein. The peptides content after protein hydrolysis derived from raw and heat treated beans were noted 2.10 and $2.50 \mathrm{mg} \cdot \mathrm{ml}^{-1}$, respectively. The hydrolysates obtained from raw (PHR) and heat treated (PHT) beans showed better antioxidant properties than protein isolates (PIR and PIT). Moreover, the hydrolysates obtained from heat treated beans showed the higher ability to scavenge DPPH ${ }^{*}$ $(46.12 \%)$ and $\operatorname{ABTS}^{+\cdot}(92.32 \%)$ than obtained from raw beans (38.02\% and $88.24 \%$, correspondingly). The $\mathrm{IC}_{50}$ value for $\mathrm{Fe}^{2+}$ chelating ability for pepsin hydrolysates obtained from raw and heat treatment beans were noted 0.81 and $0.19 \mathrm{mg} \cdot \mathrm{ml}^{-1}$, respectively. In conclusion, the results of this study showed that the heat treatment string beans caused increase in the antioxidant activities of peptide-rich hydrolysates.
\end{abstract}

Key words: protein hydrolysates, bioactive peptides, antioxidant activity, yellow string bean

\section{INTRODUCTION}

Legume plants are a good source of protein, fiber, carbohydrates, many essential vitamins or minerals. Nowadays, it is known that they are also a source of various bioactive compounds including antioxidants/ peptides, and many of those compounds have important beneficial effects on human health. On the other hand, antioxidants can play an important role in food technology to improve the shelf life of foods [Di Bernardini et al. 2011], due to the fact that lipid peroxidation is a main cause of quality changes which affect the flavour, texture and appearance of foods [Rajapakse et al. 2005]. Free radicals, that inevitably form during the oxygen metabolism may contribute to the development of several diseases such as cancer, 
cardiovascular and neurological degenerative diseases or inflammation [Halliwell et al. 1995]. In recent years attention has been focused on antioxidants derived from natural sources, due to the fact that antioxidative activity of peptides and protein hydrolysates from plants or animals, in some cases, is similar or higher than that of commonly used synthetic antioxidants, such as butylated hydroxytoluene (BHA), butylated hydroxylanisole (BHT) [Samaranayaka and Li-Chan 2008]. Antioxidants can lower the pace of lipid autoxidation process, they also act as the heavy metal ions acceptors, scavengers of free radicals and are involved in anti-inflammatory processes [Ruiz-Ruiz et al. 2013]. Bioactive peptides and peptide rich hydrolysates derived from plants and animals proteins are of particular interest in the area of human nutrition and food technology due to their beneficial antihypertensive, anticancer, hypocholesterolemic, anti-inflammatory and antioxidant properties [Chakrabarti et al. 2014, Hartmann and Meisel 2007]. The ability to ions chelating, scavenge or neutralize free radicals, oxygen quencher or hydrogen donor has been described as antioxidative properties [Moure 2006]. It is reported that transition metal ions (e.g. $\mathrm{Fe}^{2+}$ or $\mathrm{Cu}^{2+}$ ) are involved in many oxidation reactions in vitro. These ions can catalyse Haber-Weiss reaction and induce superoxide anion to form more hazardous hydroxyl radicals that react rapidly with the adjacent biomolecules and cause severe damage. One of the products formed in Fenton reaction is $\mathrm{Fe}^{2+}$, where hydrogen superoxide produces hydroxyl radical [Afans et al. 1989]. It was found that the scavenging of hydroxyl radicals by antioxidant was effective mainly via chelating of metal ions [Gordon 1990]. These have been at least partially attributed to the presence of biologically active components in beans (other legume plants) especially polyphenols [Xu and Chang 2008, Gawlik-Dziki et al. 2012] or peptides that can be released from plants or animals proteins during digestion or technology process as microwave cooking, heating or frozen process [Karaś and Baraniak 2010].

Several studies have reported the antioxidant potential of biologically active peptides from protein hydrolysates [Wu et al. 2003, Iwaniak and Minkiewicz 2007, Jakubczyk et al. 2011, Carrasco-Castilla et al. 2012] but have not investigated the effect of high temperature on antioxidant of peptides derived from yellow string bean proteins. The aim of this study was to investigate the influence of heat treatment on antioxidative activity (the ability to $\mathrm{Fe}^{2+}$ chelating and radical scavenging activity) of peptides obtained from yellow bean proteins hydrolysates.

\section{MATERIAL AND METHODS}

\section{Chemicals}

The following chemicals were used: ABTS (2,2'-azinobis-(3-ethyl-benzothiazoline-6-sulphonic acid) diammonium salt); DPPH (2,2-diphenyl-1-picrylhydrazyl); TNBS (2,4,6-trinitrobenzenesulfonic); ferrozine (3-(2-pyridyl)-5,6-diphenyl-1,2,4-triazine-p,p'-disulfonic acid monosodium salt hydrate); pepsin from porcine gastric mucosa $\left(250 \mathrm{U} \cdot \mathrm{mg}^{-1}\right)$. All chemicals were of the highest analytical grade and purchased from Sigma-Aldrich Company, USA.

\section{Plant material}

The research materials were raw and boiled (10 min, $100^{\circ} \mathrm{C}$ ) frozen yellow string beans (Phaseolus vulgaris) purchased in local market.

\section{Preparation of protein isolates and enzymatic hydrolysis}

The protein isolates from raw pods yellow string beans (PIR) and heat-treated yellow string beans (PIT) were prepared according to Morales-de León et al. [2007] with slight modification. The materials were dispersed in $0.2 \% \mathrm{NaOH}$ in ratio $1: 10(\mathrm{w} / \mathrm{v})$ and protein extraction was carried out under stirring for $1 \mathrm{~h}$ at room temperature. The solutions were centrifuged for $20 \mathrm{~min}\left(8000 \mathrm{~g}, 4^{\circ} \mathrm{C}\right)$. After that, $\mathrm{pH}$ of supernatants was adjusted to the isoelectric point of bean proteins $(\mathrm{pH}=4.5)$ with $0.1 \mathrm{M} \mathrm{HCl}$. Precipitated proteins were centrifuged for $20 \mathrm{~min}, 4^{\circ} \mathrm{C}, 8000 \mathrm{~g}$ and were washed with distilled water. Isolates of protein were stored at $-18^{\circ} \mathrm{C}$ until further use.

Protein isolates (PIR and PIT) were hydrolysed by treatment with pepsin. Hydrolysis parameters were used as follows: protein isolate concentration $-4 \%$ $(\mathrm{w} / \mathrm{v})$; enzyme/substrate ratio 1:20 (w:w); temperature $37^{\circ} \mathrm{C}, \mathrm{pH}=2$. A digestion was carried out for $120 \mathrm{~min}$.

During the hydrolysis, the samples were taken every 15 minutes to determine the content of released peptides. At the end of hydrolysis the reaction mixture was 
immediately heated $\left(100^{\circ} \mathrm{C}, 5 \mathrm{~min}\right)$ to inactivate the enzyme. Hydrolysates obtained from raw bean (PHR) and heat-treated bean (PHT) were clarified by centrifuged $8000 \mathrm{~g}, 20 \mathrm{~min}$ and stored at $-18^{\circ} \mathrm{C}$ until further use.

\section{Determination of peptide concentration}

The concentration of peptides during hydrolysis of PIR and PIT was determined by the 2,4,6-trinitrobenzenesulfonic (TNBS) method using L-leucine as the standard [Adler-Nissen 1979]. All assays were performed in triplicates.

\section{$\mathrm{Fe}^{2+}$ chelation assay}

The method of Decker and Welch [1990] was used to investigate the ferrous ion chelating ability of protein isolates and hydrolysates (PIR, PIT and PHR, PHT). Briefly, the sample $(1 \mathrm{ml})$ was added to $0.02 \mathrm{ml}$ $2 \mathrm{mM} \mathrm{FeCl}_{2}$ solution and $0.04 \mathrm{ml} 5 \mathrm{mM}$ ferrozine. The mixture was shaken vigorously and incubated at room temperature for $10 \mathrm{~min}$. The absorbance was subsequently measured at $562 \mathrm{~nm}$ in the spectrophotometer. The percentage of inhibition of ferrozine- $\mathrm{Fe}^{2+}$ complex formation was calculated using the formula below:

$$
\% \text { chelating activity }=\left[1-\left(\frac{A_{s}}{A_{c}}\right)\right] \cdot 100
$$

where: $A_{s}$ - absorbance of sample, $A_{c}$ - absorbance of control.

The $\mathrm{IC}_{50}$ value (concentration of peptides to decrease $50 \%$ of $\mathrm{Fe}^{2+}$ chelating activity) was obtained from the plot of $\%$ inhibition of ferrozine- $\mathrm{Fe}^{2+}$ complex formation against concentration of bean peptides.

\section{Radical-scavenging activity}

DPPH' radical-scavenging activities. DPPH radical scavenging activity of protein isolates (PIR, PIT) and hydrolysates (PHR, PHT) was performed according to Brand-Williams et al. [1995] with slight modification. $0.2 \mathrm{ml}$ of sample was mixed with $1.8 \mathrm{ml}$ of 6 $\mu \mathrm{M}$ solution of $\mathrm{DPPH}^{\cdot}$ in $75 \%$ methanol. The absorbance of sample was determined at $515 \mathrm{~nm}$ after $10 \mathrm{~min}$ of incubation ( $75 \%$ methanol was used as a blank). Scavenging activity of the samples was expressed as the percentage of free radical-scavenging effect following the equation:

$$
\text { Scavenging activity } \%=\left[1-\left(\frac{A_{s}}{A_{c}}\right)\right] \cdot 100
$$

where: $A_{s}$ - absorbance of sample, $A_{c}$ - absorbance of control (DPPH solution).

ABTS $^{++}$radical-scavenging activities. ABTS radical cation scavenging activity of protein isolates (PIR, PIT) and hydrolysates (PHR, PHT) was determined by the method according to Re et al. [1999] with slight modification. This reaction is based on decolourization of the green solution of the free ABTS radical cation $\left(\mathrm{ABTS}^{+}\right)$. The radical solution was prepared with ABTS and potassium persulfate, diluted in ethanol, at final concentration of $2.45 \mathrm{mM}$ and left at dark for 16 $\mathrm{h}$ to allow radical development. The solution was diluted to reach absorbance measures around $0.70-0.72$ at $734 \mathrm{~nm} .1 .8 \mathrm{ml}$ ABTS $^{++}$solution was mixed with $0.04 \mathrm{ml}$ of each sample. The absorbance was measured in even minute of reaction during $10 \mathrm{~min}$ at $734 \mathrm{~nm}$. Deionized water was used as blank. Percentage inhibition of the $\mathrm{ABTS}^{++}$radical was then calculated using the equation:

$$
\text { Scavenging activity } \%=\left[1-\left(\frac{\mathrm{A}_{\mathrm{s}}}{\mathrm{A}_{\mathrm{c}}}\right)\right] \cdot 100
$$

where: $A_{s}$ - absorbance of sample, $A_{c}$ - absorbance of control (ABTS solution).

\section{Statistical analysis}

Each treatment was conducted in triplicate and the results were presented as mean \pm standard deviation. STATISTICA 7.0 was used for statistical analysis. Tukey's test was used to estimate significant differences among the mean values at the $5 \%$ probability level $(\alpha=0.05)$.

\section{RESULTS AND DISCUSSION}

For improving ability to $\mathrm{Fe}^{2+}$ chelating and antiradical properties the protein isolate obtained from raw or heat treated yellow string bean (PIR or PIT) were digested by pepsin under optimal conditions during 120 min. After this time, peptides content reached a plateau (Fig. 1). The peptides content $\left(\mathrm{mg} \cdot \mathrm{ml}^{-1}\right.$, with L-leucine as a standard) during pepsin treatment in even 15 minutes of hydrolysis process was determined and increased after enzymatic hydrolysis from $0.18 \pm 0.01$ up to $2.10 \pm 0.2$ and from $0.19 \pm 0.02$ up to $2.5 \pm 0.3 \mathrm{mg} \cdot \mathrm{ml}^{-1}$ for protein hydrolysates obtained from raw bean (PHR) and heat treatment bean (PHT), respectively. 


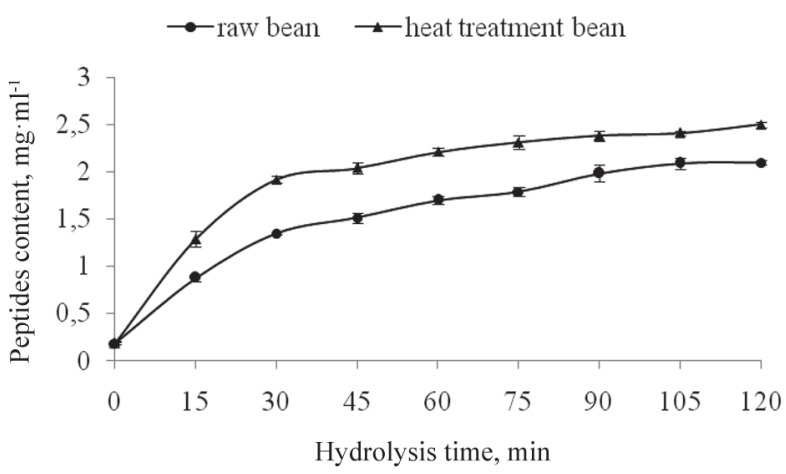

Fig. 1. Influence of time hydrolysis on release of peptides from proteins raw and heat-treated string beans

The results indicate that technology process as heat treatment had influence on improving accessibility of proteins to act by enzymes and to increase the content of peptides. The biological properties of peptides depend on the type of enzyme used and degree of proteins hydrolysis [Wu et al. 2003, Jakubczyk et al. 2011, Carrasco-Castilla et al. 2012]. During enzyme digestion, a wide various smaller peptides and free amino acids are released depending on protein specificity. Changes in size, content and composition of peptides and free amino acids affect on antioxidant activity [Wu et al. 2003].

The ability to $\mathrm{Fe}^{2+}$ chelating activity of protein isolates and pepsin hydrolysates were noted as a $\mathrm{IC}_{50}$ value. As seems in Table 1, the peptides obtained from heat-treated beans (PHT) showed the strongest $\mathrm{Fe}^{2+}$ chelating ability $\left(0.19 \pm 0.01 \mathrm{mg} \cdot \mathrm{ml}^{-1}\right)$. In hydrolyzed samples the chelating capacity increased nearly

Table 1. Comparison of $\mathrm{Fe}^{2+}$ chelating ability of protein isolates and hydrolysates obtained from string beans, expressed as $\mathrm{IC}_{50}$ value

\begin{tabular}{lcc}
\hline \multirow{2}{*}{ Sample } & \multicolumn{2}{c}{$\mathrm{IC}_{50}$ value, $\mathrm{mg} \cdot \mathrm{ml}^{-1}$} \\
\cline { 2 - 3 } & raw string bean & $\begin{array}{c}\text { heat-treated string } \\
\text { bean }\end{array}$ \\
\hline Isolate & $0.42 \pm 0.01^{\mathrm{aA}}$ & $0.33 \pm 0.02^{\mathrm{aB}}$ \\
Hydrolysate & $0.81 \pm 0.03^{\mathrm{bA}}$ & $0.19 \pm 0.01^{\mathrm{bB}}$ \\
\hline
\end{tabular}

Values with different letters superscripts are significantly different at $\alpha=0.05$. 2-fold than in samples obtained from no hydrolyzed proteins (PIR, PIT). It seems, that the conformation of protein and composition of hydrolysates caused by heat treatment increased accessibility to ferric chelating groups of yellow bean peptides. These results are corresponding well with those reported by Arcan and Yemenicioğlu [2007] that investigated effect of thermal processing on $\mathrm{Fe}^{2+}$ chelating ability crude or partially purified protein extract from chickpea and white bean. The results showed, that the thermal processing increased the $\mathrm{Fe}^{+2}$-chelating capacity of lyophilized chickpea crude protein extracts 1.8 -fold whereas it caused a 2.3 -fold reduction in the $\mathrm{Fe}^{+2}$-chelating capacity of lyophilized white bean crude protein extracts [Arcan and Yemenicioğlu 2007]. Moreover, the heat treatment had also influence on ions chelating ability of peptides from loach proteins. The peptides obtained from heat treated material $\left(63^{\circ} \mathrm{C}, 30 \mathrm{~min}\right.$ and $121^{\circ} \mathrm{C}$, $15 \mathrm{~min}$ ) were characterized by higher $\mathrm{Cu}^{2+}$ chelating activity than the proteins treated at $100^{\circ} \mathrm{C}, 20 \mathrm{~min}$ [You et al. 2012]. Zhu et al. reported that the specific peptide structure and amino acid side chain groups played an important role in terminating the free radical chain reactions and also in chelating transition metal ions [Zhu et al. 2008].

The antiradical activity was measured as ability to reduce $\mathrm{DPPH}^{\cdot}$ and $\mathrm{ABTS}^{\cdot+}$ by peptides obtained from yellow bean proteins hydrolysates. As shown

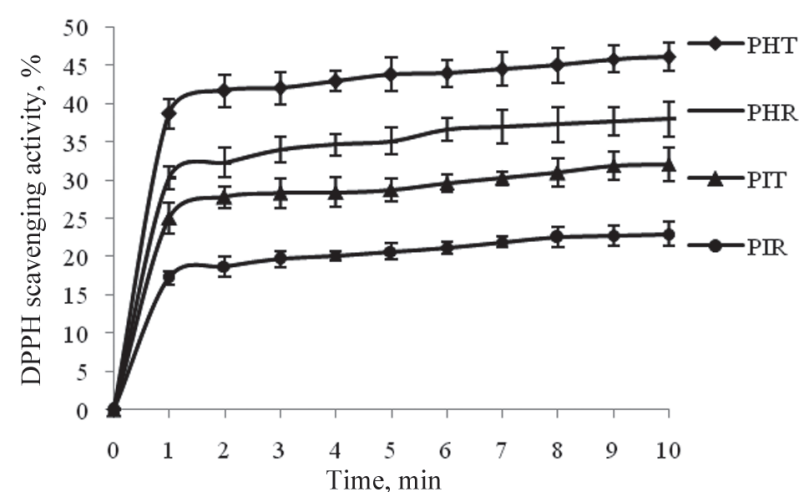

Fig. 2. Comparison of DPPH' scavenging capacities of protein isolates and hydrolysates obtained from string bean: PIR - protein isolate from raw bean, PHR - protein hydrolysates from raw bean, PIT - protein isolate from heat treated bean, PHT - protein hydrolysates from heat treated bean 


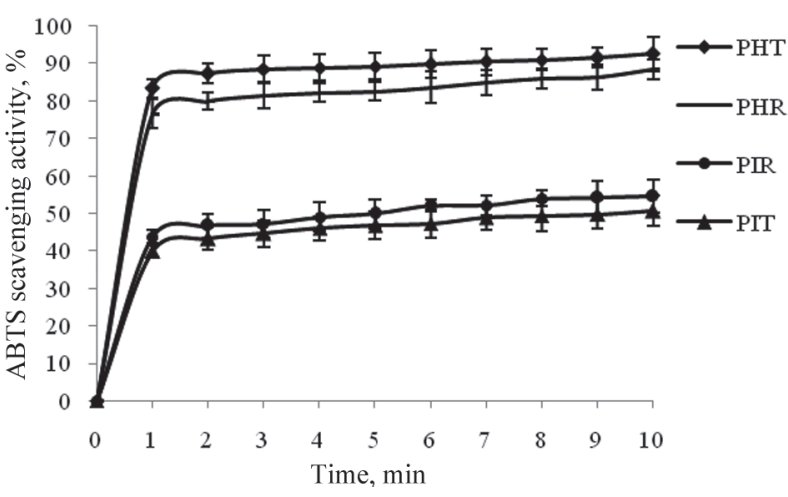

Fig. 3. Comparison of $\mathrm{ABTS}^{++}$scavenging capacities of protein isolates and hydrolysates obtained from string bean: PIR - protein isolate from raw bean, PHR - protein hydrolysates from raw bean, PIT - protein isolate from heat treated bean, PHT - protein hydrolysates from heat treated bean

in Figure 2 the value of DPPH radical scavenging activity increased to the greatest extent for peptides derived from hydrolysates from protein after heat treatment and it was noted as $46.12 \%$.

The higher antiradical activity against $\mathrm{DPPH}^{\bullet}$ was determined for PHT and PHR $(46.12 \pm 1.84 \%$ and $38.02 \pm 2.28 \%)$ than for PIR or PIT $(22.99 \pm 1.60 \%$ and $32.09 \pm 2.24 \%$, respectively).

Moreover, the ABTS radical scavenging activity (Fig. 3) of peptides from both PHR and PHT (88.24 \pm 2.64 and $92.35 \pm 4.31 \%$, respectively) increased nearly 2 -fold higher than activity of protein isolates PIR and PIT (54.36 \pm 4.34 and $50.54 \pm 4.04 \%$ ). The similar results were obtained in previous study where protein obtained from pea sprouts was hydrolysed by pepsin and the antiradical activity was measured. The ABTS radical scavenging activity of peptides was noted $99.57 \%\left(0.2 \mathrm{mg} \cdot \mathrm{ml}^{-1}\right)$ and was 5-fold higher than antiradical activity of raw protein [Jakubczyk et al. 2011]. The heat treatment process contributed to the improved accessibility of peptide bonds to the proteases and this resulted in higher release of the antioxidant peptides. The reason of significant changes of antioxidant activity against $\mathrm{ABTS}^{++}$and $\mathrm{DPPH}^{\circ}$ may be that during heat treatment and hydrolysis of bean proteins the compositions of free amino acids and released peptides were changed and more hydrophilic amino residue side chain groups were exposed [Zhu et al. 2008]. Thus, they better react with hydro-soluble
ABTS solution than with lipid-soluble DPPH solution [You et al. 2012].

\section{CONCLUSION}

Obtained results indicate, that the heat treatment process significantly influences the antiradical activity and $\mathrm{Fe}^{2+}$ chelating ability of peptide-rich protein hydrolysates obtained after pepsin hydrolysis. These peptides can be used as additives or compounds to functional foods. These results should be supported by the study of effect of heat treatment of yellow bean on release of antioxidant peptides during hydrolysis under gastrointestinal conditions.

\section{REFERENCES}

Adler-Nissen J., 1979. Determination of the degree of hydrolysis of food protein hydrolysates with trinitrobenzenesulfonic acid. J. Agric. Food Chem. 27(6), 1256-1262.

Afans E.B., Dorozhko A.I., Brodskii A., Kostyuk V.A., Potapovitch A., 1989. Chelating and free radical scavenging mechanisms of inhibitory action of rutin and quercetin in lipid peroxidation. Biochem. Pharmacol. 38(11), 1763-1989.

Arcan I., Yemenicioğlu A., 2007. Antioxidant activity of protein extracts from heat-treated or thermally processed chickpeas and white beans. Food Chem. 103, 301-312.

Brand-Williams W., Cuvelier M., Berset C., 1995. Use of a free radical method to evaluate antioxidant activity. LWT Food Sci. Technol. 28, 25-30.

Carrasco-Castilla J., Hernández-Álvarez A.J., Jiménez-Martínez C., Jacinto-Hernández C., Alaiz M., Girón-Calle J., Vioque J., Dávila-Ortiz G., 2012. Antioxidant and metal chelating activities of peptide fractions from phaseolin and bean protein hydrolysates. Food Chem. 135 (3), 1789-1795.

Chakrabarti S., Jahandideh F., Wu J., 2014. Food-derived bioactive peptides on inflammation and oxidative stress. BioMed Res. Int. ID 608979, 1-12.

Decker E.A., Welch B., 1990. Role of ferritin as a lipid oxidation catalyst in muscle food. J. Agric. Food Chem. 38 (3), 674-677.

Di Bernardini R., Harnedy P., Bolton D., Kerry J., O’Neill E., Mullen A.M., Hayes M., 2011. Antioxidant and antimicrobial peptidic hydrolysates from muscle protein sources and by-products. Food Chem. 124 (4), 1296-1307.

Gawlik-Dziki U., Świeca M., Dziki D., 2012. Comparison of phenolic acids profile and antioxidant potential of 
six varieties of spelt (Triticum spelta L.). J. Agric. Food Chem. 60, 4603-4612.

Gordon M.H., 1990. The mechanism of the antioxidant action in vitro. Food Antioxidants. Elsevier Appl. Sci. New York, 1-18.

Halliwell B., Murcia M.A., Chirico S., Arumoma O.I., 1995. Free radicals and antioxidants in food and in vivo: What they do and how they work. Crit. Rev. Food Sci. 35 (1-2), 7-20.

Hartmann R., Meisel H., 2007. Food-derived peptides with biological activity: from research to food applications. Curr. Opin. Biotechn. 18 (2), 163-169.

Iwaniak A., Minkiewicz P., 2007. Proteins as the source of physiologically and functionally active peptides. Acta Sci. Pol., Technol. Aliment. 6, 5-15.

Jakubczyk A., Karaś M., Baraniak B., 2011. Antihypertensive and antioxidative activity of peptides derived from pea sprouts (Pisum sativum) protein hydrolysates. Ann. Mariae Curie-Sklodowska, Sect. DDD, Pharm. 24 (3) 175-1782.

Karaś M., Baraniak B., 2010. Use of selected metal ions for the separation of peptides isolated from thermally processed string beans. J. Elementol. 15 (2), 291-300.

Morales-de León J.C., Vázquez-Mata N., Torres N., Gil-Zenteno L., Bressani R., 2007. Preparation and characterization of protein isolate from fresh and hardened beans (Phaseolus vulgaris L.). J. Food Sci. 72 (2), 96-102.

Moure A., Dominguez H., Parajó J.C., 2006. Antioxidant properties of ultrafiltration-recovered soy protein fractions from industrial effluents and their hydrolysates. Process Biochem. 41, 447-456.
Rajapakse N., Mendis E., Byun H.G., Kim S.K., 2005. Purification and in vitro antioxidative effects of giant squid muscle peptides on free radical-mediated oxidative systems. J. Nutr. Biochem. 16, 562-569.

Re R., Pellegrini N., Proteggente A., Pannala A., Yang M., Rice-Evans C., 1999. Antioxidant activity applying an improved ABTS radical cation decolorization assay. Free Radic. Biol. Med. 26 (9-10), 1231-1237.

Ruiz-Ruiz J., Dávila-Ortíz G., Chel-Guerrero L., Betancur-Ancona D., 2013. Angiotensin I-converting enzyme inhibitory and antioxidant peptide fractions from hard-tocook bean enzymatic hydrolysates. J. Food Bioch. 37, 26-35.

Samaranayaka A.G.P., Li-Chan E.C.Y., 2008. Autolysisassisted production of fish protein hydrolysates with antioxidant properties from Pacific hake (Merluccius productus). Food Chem. 107, 768-776.

Wu H.C., Chen H.M., Shiau C.Y., 2003. Free amino acids and peptides as related to antioxidant properties in protein hydrolysates of mackerel (Scomber austriasicus). Food Res. Int. 36, 949-957.

Xu B.J., Chang S.K.C., 2008. Total phenolic content and antioxidant properties of eclipse black beans (Phaseolus vulgaris L.) as affected by processing methods. J. Food Sci. 73 (2), 19-27.

You L., Zheng L., Regenstein J.M., Zhao M., Liu D., 2012. Effect of thermal treatment on the characteristic properties of loach peptide. Int. J. Food Sci. Technol. 47 (12), 2574-2581.

Zhu L.J., Chen J., Tang X.Y., Xiong Y.L., 2008. Reducing, radical scavenging, and chelation properties of in vitro digests of alcalase-treated zein hydrolysate. J. Agric. Food Chem. 56, 2714-2721.

\section{AKTYWNOŚĆ PRZECIWUTLENIAJĄCA HYDROLIZATÓW BIAŁKOWYCH OTRZYMANYCH Z SUROWEJ I PODDANEJ OBRÓBCE TERMICZNEJ ŻÓŁTEJ FASOLI SZPARAGOWEJ (PHASEOLUS VULGARIS L.)}

\section{STRESZCZENIE}

Obecnie rośliny strączkowe są uznawane nie tylko za źródło wartościowego białka niezbędnego do prawidłowego funkcjonowania i wzrostu, ale także źródło biologicznie aktywnych peptydów, które mogą korzystnie wpływać na zdrowie ludzi oraz zapobiegać niekorzystnym zmianom zachodzącym w żywności. Celem badań było określenie wpływu obróbki cieplnej na właściwości przeciwutleniające peptydów uzyskanych w wyniku hydrolizy białek żółtej fasoli szparagowej. Właściwości przeciwutleniające hydrolizatów wyrażono jako zdolności do neutralizacji wolnych rodników (DPPH• i $\mathrm{ABTS}^{+*}$ ) i chelatowania jonów żelaza (II). Otrzymane wyniki wykazały, iż obróbka cieplna znacząco wpłynęła zarówno na podatność białek fasoli szparagowej na działania pepsyny, jak i uwolnienie peptydów o właściwościach przeciwutleniających. Oznaczona zawartość peptydów po hydrolizie białek surowej i ugotowanej fasoli wyniosła odpowiednio: 2,10 i 2,5 $\mathrm{mg} \cdot \mathrm{ml}^{-1}$. 
Karaś M., Jakubczyk A., Szymanowska U., Materska M., Zielińska E., 2014. Antioxidant activity of protein hydrolysates from raw and heat-treated yellow string beans (Phaseolus vulgaris L.). Acta Sci. Pol., Technol. Aliment. 13(4), 385-391.

Hydrolizaty otrzymane z surowych (PHR) oraz poddanych obróbce termicznej (PHT) strąków fasoli odznaczały się lepszymi właściwościami przeciwutleniającymi niż izolaty białkowe (PIR i PIT). Ponadto hydrolizaty otrzymane z poddanych obróbce termicznej strąków fasoli wykazywały większą zdolność do neutralizowania wolnych rodników DPPH ${ }^{\bullet}(46,12 \%)$ i ABTS $^{+}(92,32 \%)$ niż hydrolizaty uzyskane z fasoli surowej (odpowiednio 38,02\% i 88,24\%). Hydrolizaty białkowe otrzymane z surowych oraz poddanych obróbce termicznej strąków fasoli wykazywały zdolność do chelatowania jonów $\mathrm{Fe}^{2+}$, która wyrażona jako wartość $\mathrm{IC}_{50}$ wyniosła odpowiednio $0,81 \mathrm{i} 0,19 \mathrm{mg} \cdot \mathrm{ml}^{-1}$. Podsumowując, wyniki prezentowanych badań wykazały, że obróbka cieplna wpłynęła na polepszenie właściwości przeciwutleniających bogatych w peptydy hydrolizatów białek fasoli szparagowej.

Słowa kluczowe: hydrolizaty białkowe, bioaktywne peptydy, aktywność przeciwutleniająca, żółta fasola szparagowa

Received - Przyjęto: 9.05.2014

Accepted for print - Zaakceptowano do druku: 2.07.2014

For citation - Do cytowania

Karaś M., Jakubczyk A., Szymanowska U., Materska M., Zielińska E., 2014. Antioxidant activity of protein hydrolysates from raw and heat-treated yellow string beans (Phaseolus vulgaris L.). Acta Sci. Pol., Technol. Aliment. 13(4), 385-391. 